\title{
Regional Inequality Based on Infrastructure Indicators Using Principal Component Analysis (PCA)
}

\author{
By: \\ Kikin Windhani ${ }^{1)}$, Fajar Hardoyono ${ }^{2)}$ \\ ${ }^{1)}$ Faculty of Economics and Business, Universitas Jenderal Soedirman \\ ${ }^{2)}$ Faculty of Tarbiyah and Educational Sciences, IAIN Purwokerto \\ ${ }^{1)}$ Email: kikin_025@yahoo.com
}

\begin{abstract}
This research aims to identify the development gap among 27 sub-districts in Banyumas Regency based on infrastructure indicators using Principal Component Analysis (PCA). The infrastructure indicators that we used are the quality of road, electricity, transportation, market, bridges and schools. Our analysis found that, the sub-districts in Banyumas Regency were divided into 4 clusters, there are Cluster I consist of 1 sub-district, Cluster II consists of 3 sub-districts, Cluster III consists of 3 sub-districts, and the remaining 20 subdistricts were in Cluster IV.
\end{abstract}

Keywords: Gap, Infrastructure, Principal Component Analysis (PCA).

\begin{abstract}
ABSTRAK
Penelitian ini bertujuan untuk mengidentifikasi celah pembangunan diantara 27 kecamatan di Kabupaten Banyumas berdasar indicator-indikator infrastruktur dan dianalisa menggunakan Principal Component Analysis (PCA). Indikator-indikator infrastruktur tersebut meliputi kualitas jalan, listrik, transportasi, pasar, jembatan, dan sekolah. Hasil analisis yang kami lakukan menemukan bahwa kecamatan-kecamatan di Kabupaten Banyumas dibagi ke dalam empat kelompok/klaster. Klaster I terdiri dari satu kecamatan, Klaster II terdiri dari tiga kecamatan, Klaster III tediri dari tiga kecamatan, dan ke dua puluh kecamatan sisanya masuk ke dalam Klaster IV.
\end{abstract}

Keywords: Gap, Infrastruktur, Principal Component Analysis (PCA).

\section{INTRODUCTION}

The main objective of national development is to promote common prosperity and to implement social justice. However, to pursue these goals is not an easy way. There are several problems faced by Indonesian to achieve its development goals. Differences in geographical conditions is one of them. It have caused imbalance development among regions, especially in infrastructure development. Previous research by Fleisher et al. (2010) who examined the growth pattern in China, found that regional inequality was influenced by regional differences in physical, human and infrastructure capital.

Study conducted by Del Bo and Florio (2012) who examined the European Union policy to boost infrastructure for the 2003 to 2013 period had found that there are significant and positive role of infrastructure investment to the level of GDP. Their findings was that the highest return on infrastructure investment were in the telecommunication and the quality and accessibility of transportation network.

Infrastructure is one indicator to determine the success of national development. If the infrastructure in a region is evenly built, then it can be said that development will be enjoyed by the whole community. Otherwise, if infrastructure development is unevenly built, then it can be said that there is imbalance development in the region. 
Our research focused on the infrastructure development in Banyumas Region/Regency. This regency is strategic area because from accessibility view, it connects directly with West Java Province through main national road. Theoretically, the areas with access to main national road will have high economic growth compared to the remote areas. This regency is also as one of the regencies in southern part of Central Java Province that consists of 27 sub-districts with different geographical conditions. There are several sub-districts which located in the lowlands and other sub-districts located in mountainous areas. This geographical differences in sub-district of Banyumas Regency, encourage us to do mapping of some sub-districts in Banyumas Regency using some of infrastructure indicators.

The mapping of economic inequality among regencies and cities in Central Java was conducted to cluster the regencies/cities in Central Java Province based on the level of infrastructure development in regions. Through this mapping, we can determined which areas that fall into the category of developed, moderately developed or underdeveloped regions. Therefore, we were interested to examine Regional Inequality based on Infrastructure Indicators in Banyumas Regency.

In order to identify and clustering sub-district in Banyumas Regency, we use Principal Component Analysis. This analysis is multivariate technique that involved inter-related dependent variables and considered as non-parametric analysis (Abdi and Williams, 2010). PCA according to Abson et al. (2012) is ordination of observed data that converts some potentially correlated variables into set of uncorrelated variable that capture variability of the observed data.

PCA has been used to measure the degree of areas similarity among sub-districts in Banyumas in terms of social and economic indicators, where the areas will be clustered with the same degree of inequality (Windhani et al., 2016).

\section{RESEARCH METHOD}

Our research was categorized as survey research. The data analyzed were mostly primary data from survey in all sub-districts in Banyumas Regency. Meanwhile, secondary data were sourced from Bank Indonesia, National Central Statistics Agency (BPS), BPS of Central Java Province and BPS of Banyumas Regency. This research was conducted in 27 sub-districts in Banyumas Regency divided into 5 research zones, namely City Zone: West Purwokerto, East Purwokerto, South Purwokerto, North Purwokerto, Kembaran, and Sokaraja; East Zone: Tambak, Sumpyuh, Kemranjen, Banyumas, Kalibagor, and Somagede; West Zone: Pekuncen, Ajibarang, Gumelar, Cilongok, and Karanglewas; North Zone: Baturaden, Sumbang and Kedungbanteng and South Zone: Wangon, Lumbir, Jatilawang, Rawalo, Kebasen, Purwojati, and Patikraja.

The variables measured in this research were:

(1) The level of infrastructure development gap among regions in Banyumas Regency.

(2) The map of infrastructure development gap among regions in Banyumas Regency.

The infrastructure indicators used as the basis for analysis were:

(1) Road quality: percentage of road length in all sub-districts.

(2) Lighting quality: total of sub-districts that have been electrified.

(3) Transportation quality: percentage of accessible villages by public transportation.

(4) Market quality: number of markets in all sub-districts.

(5) Bridge quality: percentage of bridges with good condition compared to damaged bridges in all the sub-districts.

(6) School quality: number of school buildings in a sub-district.

We used Principal Component Analysis (PCA) method in conducting our research. PCA is a method to identify patterns in data and then transforming the data into other form to show differences and similarities between the patterns (Jollife, 2002). PCA will analyze observed data table that described by several dependent variables which are inter-correlated and extract the important information into orthogonal variables called principal components or PC (Zhou et al. 2011).

However, reducing the dimensionality does not eliminate much information because PCA aims to obtain first principal component variable $\left(\mathrm{PC}_{1}\right)$ and second principal component variable $\left(\mathrm{PC}_{2}\right)$ which have the highest Eigen value, thus retaining the data characteristics. PCA has been used for pattern 
recognition in high-dimensional data. From this final data, it was obtained the order of principal component that has been sorted from low to high order.

PCA analysis was used as a method to reduce variables from many variables into two main variables, including $\mathrm{PC}_{1}$ and $\mathrm{PC}_{2}$ through $\mathrm{PCA}$ method. The significance value of two main variables can be determined from variance value obtained. The map of regional gap in infrastructure development can be predicted by interpolating data of $\mathrm{PC}_{1}$ and $\mathrm{PC}_{2}$ variable groups in Cartesian coordinates. Furthermore, the interpretation of regions requiring special attention in infrastructure development was obtained from the analysis of PCA plot scores and k-means clustering.

Lee (2011) conducted a research on the pattern of development and economic inequality that occurred in 6 metropolitan cities in the United States since 1970-2000. Massive development of 6 metropolitan cities in the United States since 1970-2000 led to socio-economic inequality between rural and urban areas. Guo-yong (2010) conducted a research on mapping of inter-regional innovation network in the pattern of development in China using Principal Component Analysis (PCA). The indicators used to measure regional innovation in enhancing regional economic development include the number of universities in the region, regional per capita income, job vacancies, trade volume, and regional dependence on imported goods, money supply, and value of technology product trade contract. The analysis using PCA has managed to map non-innovative areas in an effort to drive the economy.

Qin-dong and Jing (2010) conducted a research on evaluation of regional innovation ability in the development process in China. The indicators used to measure regional innovation in the acceleration of development were community knowledge, advancement of science and technology in the local area, economic force, and performance of local government institutions. From the aspect of economic force, the variables used to measure local innovation ability to drive development included per capita income, number of heavy, medium and small industries, sales volume of technology products, and household income. PCA analysis has managed to cluster regions that were noninnovative and slow in the development process. Clausen (2010) conducted a research on economic globalization and inter-regional inequality occurred in the Philippines. Economic growth was centered only in major cities in the Philippines. There was a significant imbalance between the growth centers in big cities and rural areas in the Philippines. The indicators used to measure the inequality of interregional economic development were per capita income, Gross Regional Domestic Product (GRDP), population, volume of agricultural products, household income, volume of trade in goods and services.

\section{RESULT AND DISCUSSION}

\section{Profile of Infrastructure Development}

The infrastructure development is an indicator of physical development in a region. Every year, the local government of Banyumas Regency allocates Regional Budget (APBD) for physical development in all sub-districts and villages spreading in Banyumas Regency areas. Physical development becoming the main target of villages and sub-districts infrastructure development examined by the researcher includes:

(1) Road construction measured from: road length (kilo meter); percentage of accessible road compared to the total road length in sub-district areas.

(2) Construction of electricity network measured from the percentage of total sub-districts that have been electrified.

(3) Construction of transportation means measured from: percentage of villages accessible by public transportation, including public transportation, motorcycle, car and truck; percentage of isolated villages which are barely accessible by public transportation, including public transportation, motorcycle, car and truck.

(4) Market development measured from: number of markets in all sub-districts of Banyumas Regency; percentage of market quality A (central market) with overview of (Wage Market and Ajibarang Market) compared to the number of markets in all sub-districts; percentage of market quality B (moderate market) with overview of (Manis Market and Pon Market) 
compared to the number of markets in all sub-districts; percentage of market quality C (small market) with overview of (Glempang Market, Proliman Market, Cikebrok Market) compared to the number of markets in all sub-districts.

(5) Construction of bridge, measured from: number of bridges in a sub-district; percentage of bridges connecting to state roads (for example, Serayu River Bridge, Tajum River Bridge); percentage of bridges connecting to regency/sub-district road; percentage of bridges connecting to village road; percentage of bridges with good condition compared to damaged bridges in all the sub-districts.

(6) Construction of school buildings, measured from: the number of school buildings in a subdistrict from primary, secondary and high schools both public and private; number of school buildings for early-childhood education institutions (PAUD); number of school buildings for primary school and equivalent; number of school buildings for high school and equivalent; number of school buildings for higher education; percentage of damaged and inadequate school buildings from primary, secondary to high schools both public and private.

Table 1. Progress of Infrastructure Development in 27 Sub-Districts in Banyumas Regency Based on Road and Lighting Indicators

\begin{tabular}{|c|c|c|c|c|c|}
\hline \multirow[b]{2}{*}{$\begin{array}{l}\text { Sub- } \\
\text { District } \\
\text { Code } \\
\text { Number }\end{array}$} & \multirow[b]{2}{*}{ Sub-District Name } & \multicolumn{4}{|c|}{ Indicators of Infrastructure Development (Road and Lighting) } \\
\hline & & $\begin{array}{l}\text { Road Length } \\
\text { of Across } \\
\text { Sub-District } \\
(\mathrm{km})\end{array}$ & $\begin{array}{l}\text { Percentage of } \\
\text { Paved Road, } \\
\text { Cement } \\
\text { Concrete } \\
\text { Road, etc. (\%) }\end{array}$ & $\begin{array}{c}\text { Percentage of } \\
\text { Road } \\
\text { Accessible by } \\
\text { Light Vehicles } \\
(\%)\end{array}$ & $\begin{array}{c}\text { Percentage of } \\
\text { Areas with } \\
\text { Electricity }(\%)\end{array}$ \\
\hline 1 & Ajibarang & 228.58 & 75.00 & 0.00 & 100.00 \\
\hline 2 & Banyumas & 102.25 & 87.67 & 0.00 & 100.00 \\
\hline 3 & Baturraden & 58.77 & 80.00 & 0.00 & 100.00 \\
\hline 4 & Cilongok & 76.64 & 85.00 & 0.00 & 100.00 \\
\hline 5 & Gumelar & 64.70 & 70.00 & 0.00 & 100.00 \\
\hline 6 & Jatilawang & 55.00 & 90.00 & 0.00 & 100.00 \\
\hline 7 & Kalibagor & 34.72 & 80.00 & 0.00 & 100.00 \\
\hline 8 & Karanglewas & 49,75 & 80.00 & 3.00 & 100.00 \\
\hline 9 & Kebasen & 61.71 & 85.00 & 0.00 & 100.00 \\
\hline 10 & Kedungbanteng & 43.31 & 80.00 & 0.00 & 100.00 \\
\hline 11 & Kembaran & 32.54 & 90.00 & 0.00 & 100.00 \\
\hline 12 & Kemranjen & 58.87 & 75.00 & 0.00 & 100.00 \\
\hline 13 & Lumbir & 70.00 & 65.00 & 0.00 & 99.00 \\
\hline 14 & Patikraja & 55.44 & 90.00 & 0.00 & 100.00 \\
\hline 15 & Pekuncen & 39.00 & 62.00 & 10.00 & 95.00 \\
\hline 16 & Purwojati & 70.00 & 50.00 & 2.00 & 90.00 \\
\hline 17 & West Purwokerto & 24.03 & 95.00 & 0.00 & 100.00 \\
\hline 18 & South Purwokerto & 33.16 & 95.00 & 0.00 & 100.00 \\
\hline 19 & East Purwokerto & 33.71 & 95.00 & 0.00 & 100.00 \\
\hline 20 & North Purwokerto & 17.47 & 95.00 & 0.00 & 100.00 \\
\hline 21 & Rawalo & 30.41 & 80.00 & 0.00 & 100.00 \\
\hline 22 & Sokaraja & 74.01 & 94.00 & 0.00 & 100.00 \\
\hline 23 & Somagede & 30.81 & 80.00 & 0.00 & 100.00 \\
\hline 24 & Sumbang & 72.33 & 80.00 & 0.00 & 100.00 \\
\hline 25 & Sumpyuh & 101.84 & 90.00 & 0.00 & 100.00 \\
\hline 26 & Tambak & 71.75 & 90.00 & 0.00 & 100.00 \\
\hline 27 & Wangon & 140.25 & 90.00 & 0.00 & 100.00 \\
\hline Average & f Banyumas Regency & 67.20 & 82.54 & 0.50 & 99.40 \\
\hline
\end{tabular}


From Table 1, it can be determined that based on the indicators of infrastructure development of road and lighting in 27 sub-districts in Banyumas Regency, the average length of road in Banyumas Regency is $67.20 \mathrm{Km}$. Ajibarang sub-district has the longest road length of $228.58 \mathrm{Km}$, followed by Wangon sub-district of $140 \mathrm{Km}$, Banyumas sub-district of $102.25 \mathrm{Km}$, and Sumpyuh sub-district of $101.84 \mathrm{Km}$. Meanwhile, the average paved road in Banyumas Regency is 82.54 percent, although the percentage indicates that most of the roads have been paved, but some sub-districts have a very farreaching percentage of the average sub-districts in Banyumas in terms of paved road, such as Purwojati, Pekuncen and Lumbir sub-districts with percentage of paved roads only about 50 percent, 62 percent, and 65 percent, respectively. As for the lighting infrastructure in sub-districts of Banyumas Regency, electrical power has generally been brought to almost all areas. In terms of accessible road condition, in general almost all roads in sub-districts of Banyumas Regency can be accessed by vehicles. However, there are few sub-districts with road condition that cannot be accessed, such as 10 percent in Pekuncen sub-district and 2 percent of road condition in Purwojati sub-district that cannot be accessed by vehicles.

Table 2. Tabulation of Data on Progress of Infrastructure Development in 27 Sub-Districts of Banyumas Regency Based on the Indicators of Quality and Quantity of Transportation and Market

\begin{tabular}{|c|c|c|c|c|c|c|c|}
\hline \multirow{2}{*}{$\begin{array}{l}\text { Sub-District } \\
\text { Code Number }\end{array}$} & \multirow{2}{*}{ Sub-District Name } & \multicolumn{6}{|c|}{$\begin{array}{l}\text { Indicators of infrastructure Development (Quality } \\
\text { and Quantity of Transportation and Market) }\end{array}$} \\
\hline & & $\mathrm{T}_{1}(\%)$ & $\mathrm{T}_{2}(\%)$ & $\mathrm{M} 1$ & $\mathrm{M}_{2}(\%)$ & $\mathrm{M}_{3}(\%)$ & $\mathrm{M}_{4}(\%)$ \\
\hline 1 & Ajibarang & 100.00 & 0.00 & 1 & 100.00 & 0.00 & 0.00 \\
\hline 2 & Banyumas & 100.00 & 0.00 & 1 & 0.00 & 100.00 & 0.00 \\
\hline 3 & Baturraden & 100.00 & 0.00 & 2 & 0.00 & 50.00 & 50.00 \\
\hline 4 & Cilongok & 100.00 & 0.00 & 2 & 50.00 & 50.00 & 0.00 \\
\hline 5 & Gumelar & 100.00 & 0.00 & 2 & 0.00 & 50.00 & 50.00 \\
\hline 6 & Jatilawang & 100.00 & 0.00 & 2 & 50.00 & 50.00 & 0.00 \\
\hline 7 & Kalibagor & 100.00 & 0.00 & 1 & 0.00 & 100.00 & 0.00 \\
\hline 8 & Karanglewas & 100.00 & 3.00 & 1 & 0.00 & 100.00 & 0.00 \\
\hline 9 & Kebasen & 100.00 & 0.00 & 1 & 0.00 & 100.00 & 0.00 \\
\hline 10 & Kedungbanteng & 100.00 & 0.00 & 1 & 0.00 & 100.00 & 0.00 \\
\hline 11 & Kembaran & 100.00 & 0.00 & 1 & 0.00 & 100.00 & 0.00 \\
\hline 12 & Kemranjen & 100.00 & 0.00 & 1 & 0.00 & 100.00 & 0.00 \\
\hline 13 & Lumbir & 100.00 & 3.00 & 2 & 0.00 & 50.00 & 50.00 \\
\hline 14 & Patikraja & 100.00 & 0.00 & 1 & 0.00 & 100.00 & 0.00 \\
\hline 15 & Pekuncen & 97.00 & 3.00 & 3 & 0.00 & 100.00 & 0.00 \\
\hline 16 & Purwojati & 100.00 & 2.00 & 2 & 0.00 & 50.00 & 50.00 \\
\hline 17 & West Purwokerto & 100.00 & 0.00 & 4 & 25.00 & 75.00 & 0.00 \\
\hline 18 & South Purwokerto & 100.00 & 0.00 & 2 & 0.00 & 50.00 & 50.00 \\
\hline 19 & East Purwokerto & 100.00 & 0.00 & 4 & 25.00 & 50.00 & 25.00 \\
\hline 20 & North Purwokerto & 100.00 & 0.00 & 1 & 0.00 & 100.00 & 0.00 \\
\hline 21 & Rawalo & 100.00 & 0.00 & 3 & 33.00 & 66.70 & 0.00 \\
\hline 22 & Sokaraja & 100.00 & 0.00 & 2 & 50.00 & 50.00 & 0.00 \\
\hline 23 & Somagede & 100.00 & 0.00 & 1 & 0.00 & 100.00 & 0.00 \\
\hline 24 & Sumbang & 100.00 & 0.00 & 1 & 0.00 & 100.00 & 0.00 \\
\hline 25 & Sumpyuh & 100.00 & 0.00 & 2 & 0.00 & 50.00 & 50.00 \\
\hline 26 & Tambak & 100.00 & 0.00 & 1 & 0.00 & 100.00 & 0.00 \\
\hline 27 & Wangon & 100.00 & 0.00 & 2 & 50.00 & 50.00 & 0.00 \\
\hline \multicolumn{2}{|c|}{ Average of Banyumas Regency } & 99.89 & 0.41 & 2 & 14.20 & 77.47 & 12.10 \\
\hline
\end{tabular}

Source: Data Processed, 2016 
Description:

$\mathrm{T}_{1}$ : Percentage of village accessible by public transportation

$\mathrm{T}_{2}$ : Percentage of isolated villages barely accessible by public transportation

$M_{1}$ : Number of markets in all sub-districts

$M_{2}$ : Percentage of market quality $A$ (central market)

$M_{3}$ : Percentage of market quality $B$ (moderate market)

$M_{4}$ : Percentage of market quality $C$ (small market)

From Table 2, it can be seen the condition of infrastructure in sub-districts of Banyumas Regency in terms of quality and quantity of transportation and the number of existing markets. Almost all villages in sub-districts of Banyumas Regency are accessible by public transportation, while the roads they cannot be accessed by public transportation are only 0.41 percent. For existing market infrastructure in sub-districts of Banyumas Regency, the average market in the category of market quality $A$ (central market) is 14.20 percent and mostly are located in Ajibarang sub-district, 77.40 percent in the category of market quality $B$ (moderate market), and 12.10 percent in the category of market quality $C$ (small market). The overview of infrastructure in terms of quality and quantity of bridges in sub-districts of Banyumas Regency can be seen in the following Table 3.

Table 3. Data on Progress of Infrastructure Development in 27 Sub-Districts of Banyumas Regency Based on the Indicators of Quality and Quantity of Bridge

\begin{tabular}{|c|c|c|c|c|c|c|}
\hline \multirow{2}{*}{$\begin{array}{l}\text { Sub-District } \\
\text { Code Number }\end{array}$} & \multirow{2}{*}{ Sub-District Name } & \multicolumn{5}{|c|}{ Indicators of Infrastructure Development (Bridge Quality) } \\
\hline & & $\mathrm{B}_{1}$ & $\mathrm{~B}_{2}(\%)$ & $\mathrm{B}_{3}(\%)$ & $\mathrm{B}_{4}(\%)$ & $\mathrm{B}_{5}(\%)$ \\
\hline 1 & Ajibarang & 17 & 1176.00 & 41.18 & 47.06 & 95.00 \\
\hline 2 & Banyumas & 12 & 16.67 & 33.30 & 50.00 & 85.00 \\
\hline 3 & Baturraden & 49 & 14.29 & 22.45 & 63.26 & 80.00 \\
\hline 4 & Cilongok & 19 & 15.79 & 15.79 & 68.42 & 75.00 \\
\hline 5 & Gumelar & 27 & 14.87 & 22.22 & 62.97 & 75.00 \\
\hline 6 & Jatilawang & 25 & 16.00 & 36.00 & 59.00 & 90.00 \\
\hline 7 & Kalibagor & 7 & 14.29 & 28.57 & 57.14 & 90.00 \\
\hline 8 & Karanglewas & 10 & 30.00 & 20.00 & 50.00 & 80.00 \\
\hline 9 & Kebasen & 27 & 11.11 & 14.81 & 74.08 & 90.00 \\
\hline 10 & Kedungbanteng & 11 & 27.27 & 0.00 & 63.64 & 90.00 \\
\hline 11 & Kembaran & 26 & 23.08 & 90.90 & 64.38 & 85.00 \\
\hline 12 & Kemranjen & 6 & 16.67 & 33.33 & 50.00 & 75.00 \\
\hline 13 & Lumbir & 30 & 13.13 & 33.33 & 53.34 & 90.00 \\
\hline 14 & Patikraja & 17 & 17.65 & 11.76 & 70.59 & 95.00 \\
\hline 15 & Pekuncen & 40 & 0.00 & 15.00 & 75.00 & 75.00 \\
\hline 16 & Purwojati & 27 & 0.00 & 11.11 & 89.90 & 70.00 \\
\hline 17 & West Purwokerto & 8 & 12.50 & 50.00 & 12.50 & 100.00 \\
\hline 18 & South Purwokerto & 13 & 31.00 & 62.00 & 7.00 & 95.00 \\
\hline 19 & East Purwokerto & 15 & 7.00 & 75.00 & 18.00 & 100.00 \\
\hline 20 & North Purwokerto & 13 & 15.38 & 53.85 & 30.77 & 90.00 \\
\hline 21 & Rawalo & 16 & 5.00 & 10.00 & 85.00 & 80.00 \\
\hline 22 & Sokaraja & 6 & 33.30 & 50.00 & 16.67 & 95.00 \\
\hline 23 & Somagede & 14 & 14.29 & 35.71 & 50.00 & 80.00 \\
\hline 24 & Sumbang & 12 & 0.00 & 33.33 & 66.70 & 75.00 \\
\hline 25 & Sumpyuh & 9 & 11.11 & 44.44 & 45.45 & 80.00 \\
\hline 26 & Tambak & 6 & 16.67 & 33.30 & 50.00 & 80.00 \\
\hline 27 & Wangon & 16 & 12.50 & 37.50 & 50.00 & 85.00 \\
\hline Average B & nyumas Regency & 18 & 57.98 & 33.88 & 53.00 & 85.19 \\
\hline
\end{tabular}


Description:

B1 : Number of bridges in a sub-district

B2 : Percentage of bridges connecting to state road (for example, Serayu River Bridge, Tajum River Bridge).

B3 : Percentage of bridges connecting to regency/sub-district road

B4 : Percentage of bridges connecting to village road

B5 : Percentage of bridges in good condition compared to damaged bridges in all sub-districts.

In Table 3, it can be seen that the average condition of bridge quality in sub-districts of Banyumas Regency has been in good condition with a value of 85.19 percent. The best condition of bridge quality is in West Purwokerto and East Purwokerto sub-districts. The average number of bridges in subdistricts of Banyumas Regency is 18 bridges. This means that each sub-district has about 18 bridges connecting to either state road, regency road or sub-district road and village road. The quality of bridge connecting to regency/sub-district road is very low with a value of 33.88 percent, meaning that the bridge quality with good condition is only 33.88 percent in the sub-districts of Banyumas Regency. While, the overview of school infrastructure in sub-districts of Banyumas Regency can be seen in table 3.4. The quality of school building is one of the infrastructure indicators used to see the regional inequality among sub-districts in Banyumas Regency using Principal Component Analysis.

Table 4. Tabulation of Data on Progress of Infrastructure Development in 27 Sub-Districts in Banyumas Regency Based on the Indicators of Quality and quantity of School Buildings

\begin{tabular}{|c|c|c|c|c|c|c|c|}
\hline \multirow{2}{*}{$\begin{array}{l}\text { Sub-District } \\
\text { Code Number }\end{array}$} & \multirow[t]{2}{*}{ Sub-District Name } & \multicolumn{6}{|c|}{$\begin{array}{l}\text { Indicators of Infrastructure Development } \\
\text { (Quality and Quantity of School Buildings) }\end{array}$} \\
\hline & & $\mathrm{S}_{1}$ & $\mathrm{~S}_{2}$ & $\mathrm{~S}_{3}$ & $\mathrm{~S}_{4}$ & $\mathrm{~S}_{5}$ & S6 (\%) \\
\hline 1 & Ajibarang & 76 & 29 & 33 & 2 & 1 & 0.00 \\
\hline 2 & Banyumas & 53 & 9 & 34 & 6 & 0 & 2.00 \\
\hline 3 & Baturraden & 46 & 15 & 27 & 2 & 0 & 1.00 \\
\hline 4 & Cilongok & 98 & 45 & 45 & 3 & 0 & 5.00 \\
\hline 5 & Gumelar & 57 & 19 & 32 & 1 & 1 & 5.00 \\
\hline 6 & Jatilawang & 73 & 27 & 36 & 5 & 0 & 0.00 \\
\hline 7 & Kalibagor & 46 & 18 & 21 & 1 & 0 & 0.00 \\
\hline 8 & Karanglewas & 45 & 16 & 22 & 2 & 0 & 2.00 \\
\hline 9 & Kebasen & 53 & 17 & 29 & 3 & 0 & 0.00 \\
\hline 10 & Kedungbanteng & 59 & 23 & 28 & 3 & 0 & 5.00 \\
\hline 11 & Kembaran & 70 & 35 & 30 & 3 & 0 & 0.00 \\
\hline 12 & Kemranjen & 69 & 22 & 34 & 8 & 0 & 2.00 \\
\hline 13 & Lumbir & 54 & 15 & 35 & 1 & 0 & 3.00 \\
\hline 14 & Patikraja & 46 & 12 & 28 & 8 & 0 & 0.00 \\
\hline 15 & Pekuncen & 68 & 26 & 35 & 0 & 0 & 3.00 \\
\hline 16 & Purwojati & 39 & 14 & 20 & 2 & 0 & 1.00 \\
\hline 17 & West Purwokerto & 45 & 16 & 23 & 0 & 1 & 0.00 \\
\hline 18 & South Purwokerto & 76 & 23 & 30 & 1 & 0 & 0.00 \\
\hline 19 & East Purwokerto & 74 & 9 & 36 & 9 & 2 & 0.00 \\
\hline 20 & North Purwokerto & 36 & 10 & 22 & 1 & 0 & 0.00 \\
\hline 21 & Rawalo & 52 & 19 & 24 & 2 & 0 & 0.00 \\
\hline 22 & Sokaraja & 77 & 32 & 33 & 9 & 2 & 0.00 \\
\hline 23 & Somagede & 39 & 15 & 19 & 1 & 0 & 0.00 \\
\hline 24 & Sumbang & 70 & 25 & 37 & 9 & 0 & 0.00 \\
\hline 25 & Sumpyuh & 60 & 17 & 30 & 9 & 0 & 0.00 \\
\hline 26 & Tambak & 46 & 10 & 28 & 3 & 0 & 0.00 \\
\hline 27 & Wangon & 65 & 10 & 45 & 1 & 0 & 0.00 \\
\hline \multicolumn{2}{|c|}{ Average of Banyumas Regency } & 59 & 20 & 30 & 4 & 0 & 1.07 \\
\hline
\end{tabular}

Source: Data Processed, 2016 


\section{Description:}

$S_{1}$ : number of all school buildings in a sub-district from primary, secondary and high schools both public and private.

$\mathrm{S}_{2}:$ number of school buildings for early-childhood education institution (PAUD)

$\mathrm{S}_{3}:$ number of school buildings for primary school and equivalent

$\mathrm{S}_{4}:$ number of school buildings for high school and equivalent

$\mathrm{S}_{5}:$ number of school buildings for higher education

$\mathrm{S}_{6}$ : percentage of damaged and inadequate school buildings for primary, secondary and high schools both public and private.

\section{Analysis of Inequality of Infrastructure Development}

Cluster analysis is the organization of a collection of members of data set having similar patterns or properties into cluster (groups) based on the similarity of patterns and properties possessed by members of data set. Members of data set clustered in a cluster will have similar characteristics. Meanwhile, members of data set that do not have same properties/patterns will be clustered into different cluster. Clustering is useful for analyzing existing patterns. In the field of engineering science, cluster analysis is commonly used in image segmentation, pattern classification, and data mining (Pan et al., 2005).

The result of cluster analysis of regional inequality among sub-districts in Banyumas Regency can be explained in the following table 3.5 and clustering based on Principal Component Analysis can be seen in the Figure 1.

Table 5. Results of Cluster Analysis of 27 Sub-Districts Based on Indicators of Infrastructure Development in Banyumas Regency

\begin{tabular}{|c|c|c|}
\hline $\begin{array}{l}\text { Cluster } \\
\text { Number }\end{array}$ & $\begin{array}{c}\text { Sub-District Name as Cluster } \\
\text { Member }\end{array}$ & Cluster Type \\
\hline 1 & Ajibarang & $\begin{array}{l}\text { Number of road length is very high }(228 \mathrm{~km}) \text {, the } \\
\text { indicators of the quality of road, lighting, } \\
\text { transportation, market, bridge and school are very } \\
\text { good. }\end{array}$ \\
\hline II & Banyumas, Sumpiuh, Wangon & $\begin{array}{l}\text { The indicators of the quality of road, lighting, bridge, } \\
\text { market are good, but number of school buildings for } \\
\text { secondary and high schools is lower than Ajibarang. }\end{array}$ \\
\hline III & $\begin{array}{l}\text { Karanglewas, Pekuncen, } \\
\text { Purwojati }\end{array}$ & $\begin{array}{l}\text { There are unpaved roads and can not be accessed by } \\
\text { light vehicles, some areas in Pekuncen have not been } \\
\text { electrified, number of markets needs to be added, } \\
\text { number of school buildings for secondary and high } \\
\text { schools needs to be added. }\end{array}$ \\
\hline IV & $\begin{array}{l}\text { Baturaden, Cilongok, Gumelar, } \\
\text { Jatilawang, Kalibagor, Kebasen, } \\
\text { Kedungbanteng, Kembaran, } \\
\text { Kemranjen, Lumbir, Patikaraja, } \\
\text { West Purwokerto, South } \\
\text { Purwokerto, East Purwokerto, } \\
\text { North Purwokerto, Rawalo, } \\
\text { Sokaraja, Somagede, Sumbang, } \\
\text { Tambak }\end{array}$ & $\begin{array}{l}\text { Number of road length is high ( } 70 \mathrm{~km} \text { in average), the } \\
\text { indicators of the quality of road, lighting, } \\
\text { transportation quality, market, bridge, and school are } \\
\text { very good. }\end{array}$ \\
\hline
\end{tabular}

Source: Data Processed, 2016 


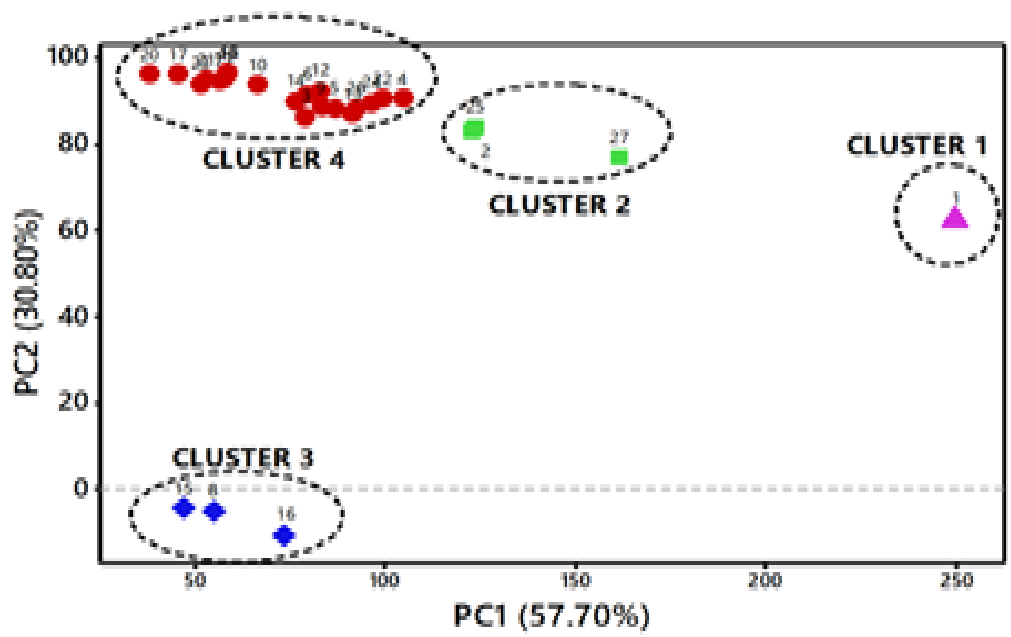

Figure 1. Clustering of 27 Sub-Districts of Banyumas Regency Based on Similarity of Indicators of Infrastructure Development

In terms of infrastructure development indicators, 27 sub-districts can be clustered into 4 clusters. Ajibarang is included in the first cluster because the sub-district has good quality of road, bridge, lighting, market and school buildings. The total length of roads in Ajibarang sub-district is $228.58 \mathrm{~km}$ which is the longest among all sub-districts in Banyumas Regency. Banyumas, Wangon, Sumpiuh sub-districts are included in the second cluster. These three sub-districts have good quality of road, lighting, bridge, market and buildings, but the percentage are lower than Ajibarang subdistrict. Meanwhile, Karanglewas, Pekuncen and Purwojati sub-districts require more attention from the Government of Banyumas Regency because these sub-districts have higher percentage of unpaved roads than other sub-districts. In addition, there are some isolated villages in Karanglewas and Pekuncen sub-districts due to barely accessible roads by light vehicles such as motorcycles, cars, rural transportations and trucks. Geographical factor is the main factor of these isolated areas.

Baturaden, Cilongok, Gumelar, Jatilawang, Kalibagor, Kebasen, Kedungbanteng, Kembaran, Kemranjen, Lumbir, Patikaraja, West Purwokerto, South Purwokerto, East Purwokerto, North Purwokerto, Rawalo, Sokaraja, Somagede, Sumbang, Tambak sub-districts are included in the fourth cluster. Generally, all indicators of infrastructure development in 20 sub-districts are almost the same as infrastructure development indicators in sub-district included in cluster I (Ajibarang sub-district), the only difference is the length of road in all sub-district which is only $70 \mathrm{~km}$. Particularly for Lumbir sub-district, eventhough the development indicators in Lumbir sub-districts are in good category, there are some villages that need special attention in improving the infrastructure development of lighting because the villages have not been electrified.

\section{CONCLUSION AND SUGGESTION}

The profile of infrastructure development indicates that 27 sub-districts have good quality of infrastructure development. Special attention to infrastructure development needs to be given to several sub-districts, including:

(1) Karanglewas, Pekuncen and Purwojati sub-districts have higher percentage of unpaved roads than other sub-districts. In addition, there are some isolated villages in Karanglewas and Pekuncen sub-districts due to barely accessible roads by light vehicles such as motorcycles, cars, rural transportations and trucks. Geographical factor is the main factor of these isolated areas.

(2) There are some villages that need special attention in improving infrastructure development of lighting because the villages have not been electrified. 


\section{REFERENCES}

Abdi, H., and Williams, L. J. (2010). Principal component analysis. Wiley Interdisciplinary Reviews: Computational Statistics, 2, 433-459.

Abson, D. J., Dougill, A. J., and Stringer L. C. (2012). Using principal component analysis for informationrich-socio-ecological vulnerability mapping in Southern Africa. Applied Geography, 35, 515-542.

Clausen, A. (2010). Economic globalization and regional disparities in the Philippines. Singapore Journal of Tropical Geography, 31, 299-316.

Del Bo, C. F., and Florio, M. (2012). Infrastructure and growth in a spatial framework: Evidence from the EU regions. Eurupean Planning Studies, 20(8), 1393-1414.

Fleisher, B., Li, H., and Zhao, M. Q. (2010). Human capital, economic growth, and regional inequality in China. Journal of Development Economics, 92, 215-231.

Guo-yong, M.A. (2010). Evaluation of regional innovation networks: Based on principal component analysis. Canadian Social Science, 6(2), 34-43.

Jollife, I. (2002). Principal component anaysis (second edition). New York: Springer Verlag.

Lee, S. (2011). Metropolitan growth patterns and metropolitan growth patterns and metropolitan areas 1970-2000. International Journal of Urban and Regional Research, 35(5), 988-1011.

Qin-dong, L.I. and Jing, N.U. (2010). Evaluation on integrated innovation capability of regions based on principal component analysis. Canadian Social Science, 6(4),12-19.

Windhani, K., Hardoyono, F., Pudjianto, H., Sambodo, H. (2016). Journal of applied economics in developing countries, 1(1).

Zhou, L., Biswas, B., Bowles, T., and Saunders, P. J. (2011). Impact of globalization on income distribution inequality in 60 countries. Global Economy Journal, 11(1), 1-16. 